\title{
連続蒸解釜の最新技術開発
}

\author{
住重アールストローム株式会社 川上千 明
}

\section{Recent Developments in the Technology of Continuous Pulping System}

W. Eric Wiley, Bruno S. Marcoccia, Masahiro Ohkubo and Chiaki Kawakami

Ahlstrom Machinery Inc.

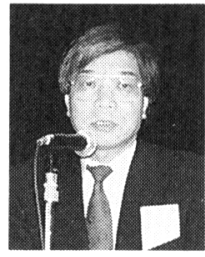

In the recent past there have been several major developments in the technology of continuous pulping systems. These developments encompass improvements in chip presteaming, in continuous chip feeding equipment, and in the process chemistry and process configuration of the cooking vessel itself. The Diamondback (TM) Chip Bin is a new atmospheric pre-steaming reactor capable of uniformly pretreating incoming wood chips without the use of any moving components. The Lo-Level (TM) Feed System is a new chip feeding system which provides for increased capacity enhanced flexibility in equipment layout, and decreased capital and operating costs. Lo-Solids (R) Pulping is new pulping process which results in improved pulp quality and improved digester operation. Combined, these developments represent a significant advancement in the technology of kraft pulping.

Keywords: Diamondback (TM) chip bin, Pre-steaming, Lo-Level (TM) Feed System, LoSolids (R) Cooking

\section{1.はじめに}

連続烝解鉒は, クラフト蒸解における主要な蒸解装 置である。全世界のクラフトパルプ生産量の半分以上 は，連続蒸解鉒によるものである。この数年間に， Ahlstrom Machinery Inc.社では連続蒸解鉒にお けるいくつかの最新技術の開発の商業化に成功した。

Diamondback (TM) チップビンの 1 号機は, 1994 年 10 月に稼動した1)。従来のプレスチーミングシス テムと異なり, Diamondback (TM) チップビンは, 駆動部分を持つことなく，ビン内でのチップ全体の均
一な動きをもたらす。この結果, 非常に良好なプレス チーミングと信頼度の高いかつメンテナンスフリーの 操業が可能となった。これらの利点のため, このプレ スチーミングシステムは全世界に急速に導入されて来 ている。1号機の操業開始から 2 年間に, 16 基の Diamondback (TM) プレスチーミングシステムが稼 動又は操業開始まで間もない状態である。

Lo-Level (TM) チップ供給システムは, 連続蒸解 法における最新の技術開発である。Lo-Level (TM) チップ供給システムの 1 号機は, 1995 年 11 月に操業 開始した2)。この新しいチップ供給システムは，加压 
システムへのチップの連続供給法を簡略化したもので ある。機器数の減少並びに建屋の省スペース化ができ るト,レイアウトも自由に設定できる。また，既存の 高圧フィーダーの能力アップも期待できる。更に, 第 1 号機の Lo-Level (TM) チップ供給システム操業経 験から, 蒸解温度の低下及びシステム全体のエネルギ 一消費の軽減などのメリットも期待できる。

Lo-Solids (R) 蒸解法は, 1993 年 10 月に 1 号機が 稼動し，それ以降 3 年間で 25 基以上のシステムが稼 動又は間もなく操業開始の状態である。このうち 2 基 は国内で稼働している。他の蒸解法に比べ，この新し い蒸解法はパルプの強度及び粘度の向上, 蒸解金から の抽出量の增加，鉒内洗浄の向上をもたらす。蒸解温 度の低下, 蒸解薬品及び漂白薬品の低減も確認されて いる。その他の利点としては, 蒸解金内での温度分布 が改善されることで蒸解の均一性が増しリジェクトが 減少すること, スケールが減少すること及び鉒内での チップコラムの交したコントロールが可能となるこ とである゙) 9)。

これら 3 つの新技術を併せたものは, 連続蒸解法の 大きな前進と方える。更に，これらの1つ1つの技術 は既存の蒸解釜に適用でき，その結果は非常に良好で ある。

\section{Diamondback (TM) プレスチーミングビン}

\section{1 背 景}

連続蒸解システムでの大気在式プレスチーミングビ ンは3つの非常に重要な機能を果たしている。

（1）チップヤードと蒸解釜供給システム間のクッシ ヨン的役割

(2) 蒸解システムの抽出液からのフラッシュ蒸気で チップを予熱する熱回收的役割

（3）チップ中の空氛の除去，系外への排出

これら 3 つの役割のうち, 最適な蒸解釜運転上, 空 気除去が最も重要である。混入空気の除去はチップ 供給システムの归滑な連転の上で必要である。空気や 他のガスの系内での蓄積は，ポンプのキャビテーショ ンや供給ラインの過度の振動につながる。また, プレ スチーミングは, 淁透ゾーンでの木材チップへの蒸解 薬液の均一な漫透を促進する。均一かつ急速な薬液浸 透が次の 2 つの理由で必要である。その第 1 はチップ 中での蒸解度の差を最少にすること，第 2 は木材チッ プ比重を增すことである。プレスチーミングが不十分, 不均一であると汶透チップの比重が周囲の蒸解液と同 じかそれより軽い状態を作り出すこともある。こうな ると，蒸解釜内でチップがスムーズに沈降せず，チッ
プコラムの動きを阻害してしまう ${ }^{11,10) 。 ~}$

大気压式プレスチーミングがリジェクト量の低減, Kappa 価制御の改善, チップコラムの安定及び動き の改善につながるのは良く知られるところである。し かし, 従来のチップビンにはいくつかの欠点, 操業上 の問題点があった。それは主としてビン底部のストー カー, バイブレータ一等の駆動部分に起因している。 メンテナンスの煩雑さ, エネルギ一消費の増加に加え, このような機構では必ずフレキシブルジョイントが必 要であった。このようなジョイント部からはガス漏れ の可能性がある。更に, 最大の欠点は従来のプレスチ ーミングビンではビン中央部のチップばかりが落下し， ビン内チップ全体が均一に排出されないことである。 図 1 では，このよjなシステムで見られる滞留時間分 布の一例を示す。このように不均一な滞留時間では, チップ全体のプレスチーミングは均一に行われない。 これらの問題を解決するため, Ahlstrom Machinery Inc. 社は, チップ全体の均一かつ十二分なプレスチ 一ミング, 安定した運転の出来る, 駆動部及びフレキ シブルジョイントを必要としないメンテナンス性の良 い，そしてコスト的に競争力のあるプレスチーミング ビンの開発を行った。

\section{2 設計原理}

重力によるプラグフロー（均一なチップの動き）は, 2つの条件が揃ったときに安定しなホッパーの運転に 見られる。その第 1 は, ホッパー壁面に対してチップ が自由に動くことができる事であり，第 2 にはチップ が安定またはそれに近い状態のブリッジを形成するよ うな塊を作らない事である。壁面に沿ったチップの動 きが阻害される場合，中心部だけが落下するようなパ ターンとなり, その結果短い滞留時間と不十分なプレ スチーミングとなる。塊またはブリッジの形成は，一 定でない滞留時間と, 最悪の場合にはコラムが完全に

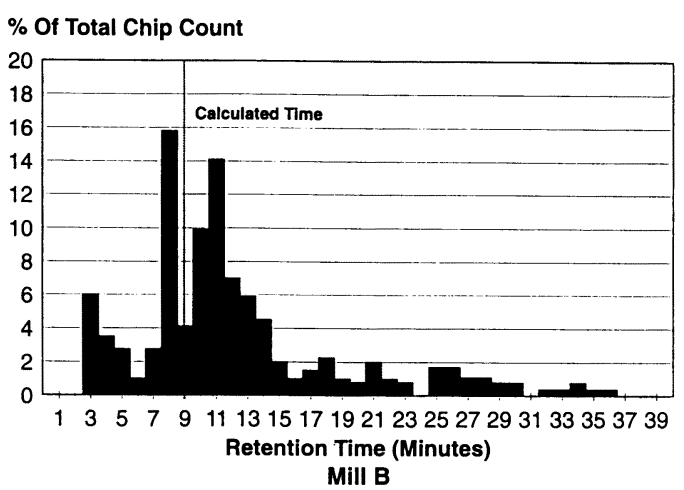

Fig. 1 プレスチーミング滞留時間分布例 
閉塞してしまう。

このうち最初の問題は, 壁面の摩擦力がチップコラ ムの下降力を越えない事で満足できる。これは, ビン 底部でのコーン形状部等, 特に壁面が傾斜を持つ場合 に重要となる。傾斜角 $\theta$ (垂直よりの角度) を持つビ ンでは，そこでの壁面での重力方向の力は,

\section{$\mathbf{F w}=\mathbf{F g} \cdot \cos \theta$}

ここで Fg は重力方向の力である。したがって，傾 斜角が増すに従って, 壁に沿った動きを作り出す力は 減少する。そのため, 傾斜角はある臨界角度 $\theta$ C 以下 でなければならない。この臨界值はプレスチーミング 後の木材チップ特性, ビンの形状及び高さ及び壁表面 の状態に依存する。これら 3 つの要素は, Johanson ${ }^{11}$ によって示された，動きが生じる限界の角度である表 面摩擦角 $(\phi)$ に影響する。

プレスチーミング後のチップは，ブリッジを支持す る部分での力（ブリッジの形成力）がチップの凝集力 を越えない限り，安定したブリッジを形成しない。ブ リッジの形成力とチップの凝集力は, ビンの形状とビ ン内での位置によって変る。例えば，プレスチーミン グ後のチップの凝集力は, トータルの圧に伴って変化 する。同様にこの統合圧力は，チップコラムの寸法に 依存する。この事は，コラムのある高さにおける垂直 方向の統合圧力 $\sigma$ として, Jansen の式 ${ }^{12)}$ で表される。

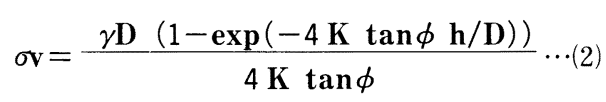

ここで, $\gamma=$ チップかさ比重, $\mathrm{D}=$ ビン直径, $\mathrm{K}=$ 実際の圧力に対する比（壁面角度に依存する定数）, $\phi=$ 表面摩擦角及び $\mathrm{h}=コ ラ ム$ 垂直高さである。かさ 比重, 通気度, 表面摩擦角及びプレスチーミング後の 凝集力は，全て統合圧力に伴って変化する。

プラグフローを得る大気圧式プレスチーミングビン の設計の第一歩は, 統合圧力, 排出部の形状及び壁面 材料によって変化するこれらのファクターの測定であ つた。この結果は, あらゆる状態での臨界角度の特定 に胕いられた。世界中の様々な工場からチップサンプ ルを集め,このテストが行われた。データの集計は現 在も継続中である。その結果, 臨界角度はそのコーン 部の形状に大きく依存する事がわかった。通常のコー ン形状では， $\theta \mathrm{c}$ は $30^{\circ}$ 以下であった。 $0^{\circ}-180^{\circ}$ 方向が 収束形状で， $90^{\circ}-270^{\circ}$ が垂直またはほぼ垂直である 棈附形状では， $\theta \mathrm{c}$ は $30^{\circ}$ 以上であった。プレスチー ミング後のチップの凝集力はチップの向きによって一 定ではない。水平に位置したチップは, 不規則に位置 したチップの 2 倍の凝集力を持つこともわかった1)。

\section{3 木材チップのスチーミングでの特別な配慮}

凝集力特性の不均一性に加えて，チップにはその弾 性による変形とその戻りの効果があり，田縮力が開放 される際に，弾性による圧縮によって縮されていな い体積部の部分的な戻りを生じる。この戻りが生じる 空間が十分でない場合，蓄積した力は開放されない。 こうなると，凝集力は劇的に増加し，岑定したブリッ ジを形成してしまう ${ }^{13)}$ 。木材チップでのテストでは, 閉じこめられた弾性力による反発によって，凝集力が 10 倍にもなることがわかった。

大気圧式プレスチーミングでは，チップ及び蒸気は 向流の状態で接触する（チップは涶直方向に移動す る)。チップの下降に対抗するビン内での液流は, 重 力による力に対抗する力となって現れる。厳しい条件 下では，非常に急な角度を持ったホッパーにおいても， これが壁面での流れを阻害する。そのため，向流の蒸 気の存在は臨界角度を変えてしまう。この変化する臨 界角度 $\theta \mathrm{cf}$ は, 無次元数である流体压力公配に依存す ることもわかった。

\section{$\theta \mathbf{c f}=\mathbf{f}(\theta \mathbf{c},(\mathbf{d P} / \mathbf{d x}) / \mathbf{g}$}

ここで, $\mathrm{P}$ は蒸気圧力である ${ }^{14)}$ 。蒸気流量の増加又 はチップコラムの通気性の減少につれ，この庄力勾配 は増加する。もし向流の蒸気流速がチップコラムの動 きを妨げる程大きければ，コラムの下降，上早の力が 拮抗してしまう。

\subsection{Diamondback（TM）チップビン}

テスト結果及び上述の設計基準に基づき，们／長们 状の断面形状のものをいくつか組み合わせた夕イプの 新しいチップビンをカナダの Weyerhaeuser 社 Kamloops 工場に納入する事になった。この形状が, Diamondback (TM) ホッパーである ${ }^{15)}$ 。

前述の長円形状はプレスチーミング後のチップに対 して大きな傾斜角を許容し，それはビン底部のスペー ス減につながる。同時に，蒸気はビン垂淔壁部から向 流として供給され，垂直壁際でのチップ流れのできる だけ阻害しないようにしている。们形，彭归形の仪束 形状の部分の配置を交互にする事で，チップの壁際か ら中心部への動きを作り出す。これにより，水平方 向の力を減じブリッジの形成が連続的に防止される ${ }^{16)}$ 。 図 2 は，大気压式プレスチーミングに用いられた Diamondback（TM）ビンの概略汹である。ビン直 胴部からチップ排出部への仪束は 4 段階で行われてい る。各段では一方向だけが仪束し，他う㓠では垂直ま

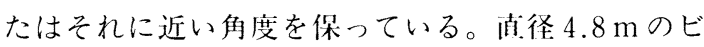
ンを例にとると, 最初の段で $4.8 \mathrm{~m}$ の直径が長さ 4.8 $\mathrm{m}$ の細長い長円状に仪束する。第 2 段では, この細 


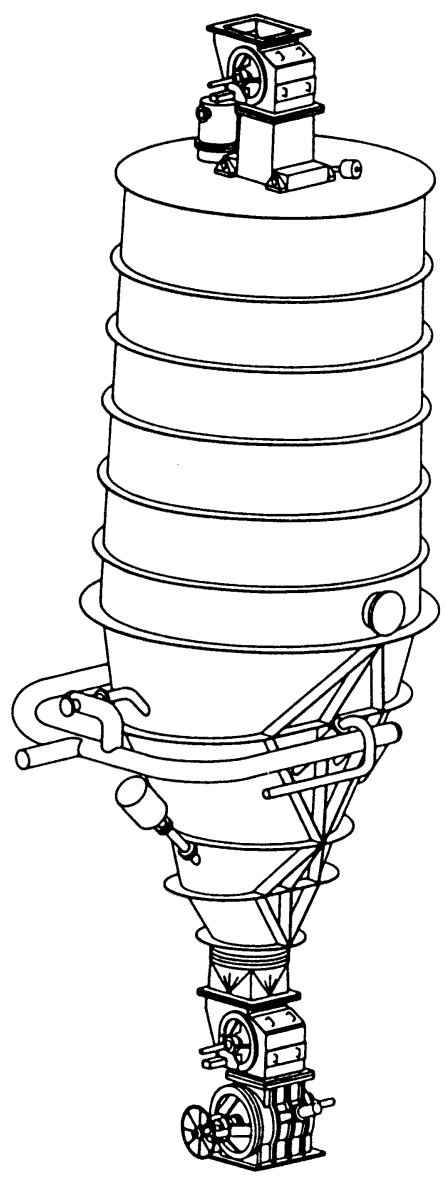

Fig. 2 Diamondback (TM) チップビン

長い長川が，その幅とほぼ间じ直径の川になるまで収 束する。これを第 $3 ， 4$ 段で同様に繰り返して，チッ プメーターに供給するシュートの径まで収束する。加 温用蒸気は，ビン直胴部へヘッダーより供給される。

\subsection{Diamondback (TM) プレスチーミング} システムの適用例

本稿作成時において，11基のシステムが稼動して おり，5基が建設中である。今までに稼動したどのシ ステムも，何等闍題なくスタートアップし，数回にわ たる滞留時間測定でも，均一なチップの動きが確認さ れている。どの場合も，チップメーターのサイトグラ スにおいて 5 分以内の時間差で排出されている。図 3 は, Weyerhaeuser 社 Kamloops 工場で実測された 滞留時間分布の一例である1”。平均滞留時間は，チッ プコラムの压縮によりかさ比重が増すため, チップか さ比重から計算されたものよりも若干長い。

本稿作成時熙で，延べ 90,000 時間の Diamondback (TM)プレスチーミングビンでの運転実績がある。シ

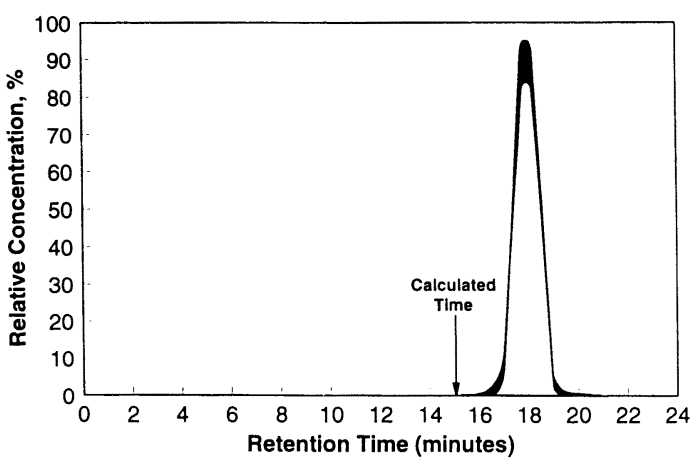

Fig. 3 プレススチーミング滞留時間分布改善例

ステムの操業安定性は $99.5 \%$ 以上に達し，この数值は 更に上昇する事が予想されている。従来のチップビン とは異なり，排出機構を止めたままのチップ供給，急 速なレベル変動やスチーミングを行ったチップの貯蔵 が可能である。従って，チップがほぼ充満した状態で の供給システムの緊急停止の場合でも, Diamondback (TM) ビンでは再スタート後アーチングを起こすこ となく, 均一でスムーズなチップの動き, 払い出しが できる。今までのプレスチーミングビンに比較して， Diamondback (TM) システムは極めて信頼性の高い ものである。

\section{Lo-Level（TM）供給システム}

\section{1 背景：連続蒸解釜での従来のチップ供給 システム}

連続蒸解鉒には 1 ベッセルまたは 2 ベッセル，気相 または液相という異なった型式があるが，どの型式の 連鉒にも同様のチップ供給システムが使用されている。 これは，チップ供給ホッパーまたはチップビン，チッ プメーター，低圧フィーダー，スチーミングベッセル， 高压フィーダー及びチップシュートとチップシュート ポンプで構成されてきた。

\subsection{Lo-Level（TM）供給システム開発の契機}

木材チップへの薬液浸透を適切に行なわれるよう， 従来のチップ供給ラインでは，スチーミングベッセル により短時間の加圧プレスチーミングを行なってきた。 しかし，ラボでの結果が示す様に，チップビンで十分 な時間，均一なプレスチーミングが行われれば良好な 浸透を得るための前処理（均一加温，十分な脱気）が 可能である。大気圧式プレスチーミングがコスト的に もより効果的・現実的である。プラグフローを持つ Diamondback (TM) チップビンはスチーミングベッ セル及び低圧フィーダーなどの中間での加圧段を必要 とせず大気圧下で最適なチップ前処理が可能である。 
従来の供給システムでは, 高圧フィーダーの入口压 力はスチーミングベッセルでの蒸気圧とチップシュー トの液レベルによるへッドで決まる。チップはスラリ 一となって高压フィーダーのポケットに供給される。 チップシュートポンプは高压フィーダーの低压側で連 続的にチップスラリーをポケットに吸引し，液を高压 フィーダー入口に帍す。チップシュートポンプの NPSH は，チップシュートの液レベルとスチーミン グベッセルの圧力による。チップシュートは高压フィ ーダー上部に位置しているため，この NPSH は供給 システムの配置高さの影響も受ける。

理論的には, 高压フィーダー入口での必要压力と液 の再循環を，チップスラリーを吸込むのではなく，逆 にチップスラリーを高归フィーダーに压送する事で行 なう事が可能である。あるパルプ工場では，木材チッ プと液の混合物をポンプによって厈送する試みがなさ

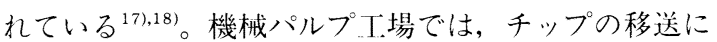
スクリュー遠心ポンプが用いられている。チップを高 压フィーダーに㞋送することで低压フィーダー，チッ プシュートポンプをなくすこと, 及び高圧フィーダー の高さを低くすることができる。この場合には，チッ プやファイバーへのポンプによる損傷が心配された。 我々も機械パルプ】場で使われているポンプの前後の チップ及びパルプの品質を調べた。その結果, チップ のサイズ分布の変化や，ポンプ後のチップのラボ蒸解 パルプの品質への影響は見られなかった。

\subsection{Lo-Level (TM) フィードシステムの開発}

上述の Diamondback (TM) チップビン及び高压 フィーダーへの新技術を併せることで, 新しいチップ 供給システム, Lo-Level (TM) フィードシステムは, チップを高厈フィーダーに供給するチップポンプを使 用する。従来のチップ供給システムに比べて, 新しい Lo-Level (TM) フィードシステムでは以下の様な利 点がある。

（1）スチーミングベッセル，低圧フィーダー，その 他の加厈機器, 及びチップシュートポンプをなく す事ができる。連釜建屋内の設置設備が少なくな り，メンテナンス及び操業コストの低減につなが る。

（2）機器配置に必要な高さ及び建屋スペースが大き く減少する。

（3）省設備, 省建屋スペースにより初期投資が低減 する。

(4) チップ供給機器レイアウトの自由度が高まる。 チップチューブから配管により高圧フィーダーに つなげるため，高压フィーダーは高さも位置も自
由に設定できる。

(5) 高圧フィーダーの能力が增加する。

(6) 既設連鉒のチップ供給ラインの能力アップ改造 がシャットダウンを要せず較的交価でできる。

(7) Lo-Solids (R) 蒸解法と共に朋いる事で, 浸透 温度を下げる事が叮能となる。この事は, 蒸解反 応プロセス及びパルプ品質を向、ささせる叮能性が ある。

米国 Alabama 州 Demopolis にある Gulf States Paper Corporationの $\mathrm{K}-1$ 蒸解釜は, この新システム開 発の理想的な設置対象であった。この鉒は2つの供給 ラインを持っており，通常はそのうちの1ラインを使 用している。そして，1年以上にわたって Lo-Solids (R) 蒸解法で運転しており ${ }^{6)}$, 既設供給システム機器 の更新が必要な状態であった。開発プログラムでは, $2 つ の$ 供給ラインの内一 $j$ を Lo-Level (TM) フィー ドシステムとし，他方は従来のまま運転できるように した。このようにして，新供給システムの運転を可能 とし，一方で、場の生産ト:のリスクを避しつつ実機 開発が行われた（図4)。

\subsection{Gulf State での Lo-Level (TM) フィードシ} ステム

Demopolis .工場での新供給システムの機器概要は, 図 5 の通りである。システムは，次のように構成され ている。

・既設チップ供給ラインの供給ホッパー頂部のゲー ト。このゲートの切替で新・川Iシステムの選択が 可能である。

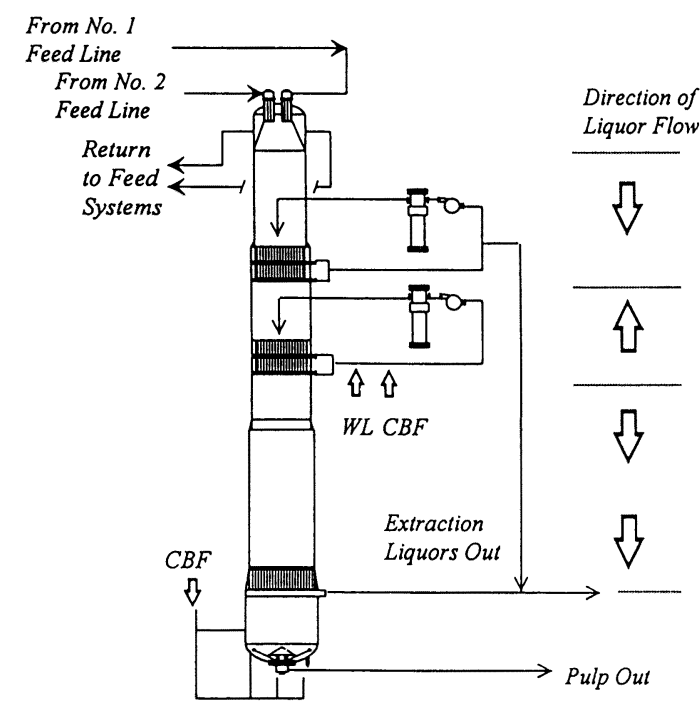

Fig. 4 K-1 䔞解釜 


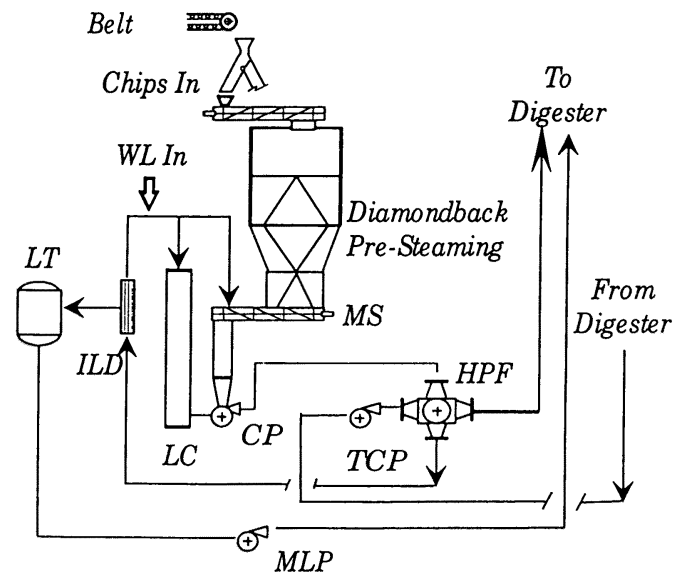

Fig. 5 Lo-Level (TM) フィードシステム

・チップ供給ベルトコンベアーからのチップを移送 する移送用スクリューコンベアー。このスクリュ ーコンベアーはエアロックを兼ねている。

・生産量 $180 \mathrm{ADMT} / \mathrm{D}$ での設計滞留時間 30 分の

Diamondback (TM) チップビン。

NCG ガスはビンからスチームエジェクターで取り 除かれている。計量ゲートによって，加圧及び真空か ら保護している。蒸気は主にDiamondback（TM） 収束部中間部に供給される。蒸気量はビン排気温度に 基づいて調節される。

・チップビンからのチップ量をコントロールする計 量スクリュー。

・計量スクリューとチップポンプをつなぐチップチ ューブ。

・チップチューブの液レベルを安定化し，そのコン トロールを助けるためのリカーチューブ。このリ カーチューブはチップビン底部に到達する高さを 持ち，液が充満した状態での Diamondback (TM) ビンの連転に使用する事ができる。通常 の連転では，チップビン及び計量スクリューとも 液が允満していない状態である。液が充満した状 態での連転（寸なわち大気圧浸透）は将来の技術 開発のためのものである。

・高化フィーダーにチップを压送するチップポンプ

・インラインドレーナーと調節弁を持つ, 高圧フィ ーダーからリカーチューブ及びチップチューブへ の戻りライン。

\subsection{Lo-Level（TM）フィードシステムの運転}

Demopolis .T場の Lo-Level (TM) フィードシステ ムは，1995年11月にスタートアップした。まず，チ
ップポンプの徹底的なテストが最初に行われた。その 結果, このポンプの特性が非常に優れている事がわか つた。その 1 つは, 流量や压力の大きな損失無しに, 沸点に近い黑液を圧送できた事である。更に，チップ チューブ及びリカーチューブでの液レベルが $1.5 \mathrm{~m}$ 以 下でこれが達成できた。チップポンプは，950 rpmで $4.2 \mathrm{~m}^{3} / \mathrm{min}$ のスラリー流量, $2 \mathrm{~kg} / \mathrm{cm}^{2}$ 以上の吐出庄 で運転している。チップ供給ラインは $360 \mathrm{ADMT} / \mathrm{D}$ の生産量で設計されている。

高圧フィーダー運転上の重要な事は, 高圧フィーダ 一のポケットに流入するチップスラリーが余計な生縮 性ガスを持なないということである。高圧フィーダー の高圧側にポケットが移動した時に, このガスが庄縮 する事で蒸解金のトップ循環ラインに衝撃を生じてし まう。この衝撃が大きいと, トップ循環ラインにひど いハンマリングを生じ，供給ラインの運転ができなく なってしまう。チップスラリーやに存在する圧縮性が スは，外部から持ち込まれた空気や気泡，または水蒸 気である。プレスチーミングが不十分だと，多量の空 気の混入が生じる。この循環での庄力損失により，压 力がその運転温度での蒸気圧以下になるとボイリング を生じる。圧力損失は，配管及び高圧フィーダーによ って生じる。

既存の古い供給システムの最低压力点はチップシュ ートポンプ入口である。この圧力は，スチーミングベ ッセルの蒸気庄力（通常 $1.0 \sim 1.2 \mathrm{~kg} / \mathrm{cm}^{2}$ ), チップ シュートの液レベル及び高压フィーダーとチップシュ 一トへの配管での圧力損失によって決まる。ポンプへ 至る圧力損失が, ポンプで必要な NPSHより低い值 となると, キャビテーションを生じる。チップシュー トポンプのキャビテーションはチップシュートのレべ ルコントロールに悪影響を及ぼし，チップシュートレ ベルの減少は高圧フィーダーのキャビテーションを起 こし，配管のハンマリングを引き起こす。ボイリング を生じる程压力損失が大きいと, 低厷での循環部に気 泡を生じ,やはり高压フィーダーのキャビテーション による配管のハンマリングを引き起こす。最悪の場合 には，高圧フィーダーでの圧力損失によって，ポケッ トの中での液のフラッシュが生じる。

既設の古いチップ供給システムでは, 高圧フィーダ 一での圧力損失は $0.3 \sim 0.5 \mathrm{~kg} / \mathrm{cm}^{2}$ の範讲で測定さ れている。これらの圧力損失は生産量 $180 \mathrm{ADMT} / \mathrm{D}$, 回転数 $8 \mathrm{rpm}$, チップシュート循環量約 $1.9 \mathrm{~m}^{3} / \mathrm{min}$ でのものである。高压フィーダーでの圧力損失が 0.6 $\mathrm{kg} / \mathrm{cm}^{2}$ を越えると, チップがシステムに供給されな くなってしまう。この圧力損失は, チップシュート循 
環流量及び高圧フィーダー回転数と共に，チップ品質 （チップサイズ分布及びファイン含有量）に依存して いる。既設供給ラインの片方だけでの針葉樹の最大生 産量は200 ADMT/Dに届いておらず，材種によって は180 ADMT/D 以下だった。

新しい Lo-Level (TM) フィードシステムでは, 最 低圧力点はチップチューブの液面である（Figure 5 参 照)。ここでは大気压となっている。気泡の形成を防 止するため, 供給システムの温度は $100^{\circ} \mathrm{C}$ 以下に保つ 必要がある。新供給システムでは, チップシュート蒸 気压 $1 \sim 1.2 \mathrm{~kg} / \mathrm{cm}^{2}$ に対して, チップ移送ラインの 座力は $2 \mathrm{~kg} / \mathrm{cm}^{2}$ である。新システムでの高い供給圧 力は, ハンマリングを起こさずに供給システムでの高 い流量を持つ事ができる。最初での圧力が高いので, ボイリングが生じる迄の許容される圧力損失が大きい。

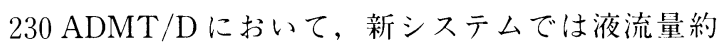
$3.4 \mathrm{~m}^{3} / \mathrm{min}$ で高压フィーダーでの圧力損失は 0.5 $\mathrm{kg} / \mathrm{cm}^{2}$ であった。高圧フィーダーの運転は良好であ り, キャビテーションは全く生じていない。チップポ ンプ吐出压力のロスによるハンマリングを防ぐため, この移送ラインの圧力低によるインターロックを高圧 フィーダーの運転に取り入れている。

\section{6 高圧フィーダー能力の増加}

チップスラリーの流量を増やし, 液のフラッシュを なくすことで, 高圧フィーダーの回転数を上げること ができる。運転可能の回転数は, $8 \mathrm{rpm}$ から $12 \mathrm{rpm}$ に上昇した。1996 年 2 月に, 供給スクリュー最大能 力の $80 \%$ での生産量テストが奉施され, 良好な結果 を得た。260Lの高圧フィーダーでの生産量は 330 $\mathrm{ADMT} / \mathrm{D}$ に相当し，これは連鉒本来の設計生産量の $60 \%$ 増に相当する。このことから, 高圧フィーダーか らの供給量を增加できることがわかった。既設チップ コンベア一能力が足りないため, 最大生産能力は確認 されていないが, 運転経験から, 供給ラインは 360 $\mathrm{ADMT} / \mathrm{D}$ (元来の実最大処理能力の $100 \%$ 増）での 運転が可能であると予測されている。その根拠として は, インラインドレーナーへの压力が $330 \mathrm{ADMT} / \mathrm{D}$ 生産時で $0.8 \mathrm{~kg} / \mathrm{cm}^{2}$ だったことである。これは, 液 のボイリングを生じることなく，より大きな圧力損失 とスラリー流量を許容できることを示している。チッ プポンプ吐出圧を高め, 高压フィーダーの回転数を上 げて，更に最大能力を引き上げることも可能である。 生産量の上限については, 将来のテストで確認する予 定である。

Demopolis 工場のレイアウトでは，チップポンプ により高圧フィーダーまでチップを水平方向に $18 \mathrm{~m}$,
垂直に $4.5 \mathrm{~m}$ 压送している。チップスラリーの配管 には, $90^{\circ}$ のルホホーが5ヶ所含まれている。これら 配管での詰まりの問題は全く生じていない。

\section{7 低温浸透}

Demopolis 工場でも Diamondback (TM) チップ ビンでのより良いチップのプレスチーミングが年想通 り達成され，スチーミングベッセル無しで十二分の脱 気処理が行われた。結果として，木釜内のチップレべ ルのコントロールが大きく改善され, 蒸铋要量もよ り安定した。

Lo-Level (TM) フィードシステムの場合, トッフ 循環と浸透ゾーンでの温度は䛤来よりも8 11 ${ }^{\circ} \mathrm{C}$ 低い。 しかし，Lo-Solids（R）蒸解法による向流加熱のため, 蒸解ゾーンでの木鉒半径方向での温度勾配は槨めて小 さく $3^{\circ} \mathrm{C}$ 以下であった。このように, 洼透ゾーンでの 温度が大きく下がっているにも拘らず, 蒸解ゾーンの 温度の均一性は全く問題なく維持された。更に注目す べき事実として, 浸透後の薬液中のアルカリの残留濃 度は増加し, 目標 Kappa への蒸解に必要な蒸解温度 が約 $3^{\circ} \mathrm{C}$ 減少し，H ファクターが減少した。

浸透温度の影響を調べるた短期的なテストとして, 浸透ゾーン温度を上下させてみた。この結果, 浸透ゾ ーン温度を下げるとブローラインの Kappa 值が減少 し，浸透温度を上げるとブローKappa が、昇する事 がわかった(この間，他の運転条件はほぼ一定)。この 現象は, 低温浸透が蒸解プロセス反応に対して重要な 影響を持つ事を示唆している。垃期間にわたる低温で の浸透が蒸解の均一性を改善し, 歩留及びパルプ強度 を向上させるとの報告が以前になされている ${ }^{19)}$ 。Gulf Stateの Demopolis T場 Lo-Level (TM)フィードシ ステムで我々が得な結果は，この報告に一致している。 スポット的にサンプルのパルプ強度のテストが行われ, 今までの結果では低温浸透によりパルプの引裂及び引 張強度が向上していることを亦している。これらのテ ストは現在進行中であり，結果が揃い次第報告する予 定である。

\section{Lo-Solids (R) 蒸解法}

\section{1 背 景}

蒸解薬液中の蒸解反応によって生じる木材溶解固形 分が, パルプ強度及び粘度の低下, 蒸解薬品消費量の 增加及びパルプ漂白性の低下゙を招くことが, ラボでの 研究によって示されている ${ }^{20,21)}$ 。この現象は, 蒸解釜 が EMCC 法で連転されている場合でも見られた。ま た，浸透ゾーンで生成する副生成物も大きく影響して いることがわかった。更に,これらの現象は, 副特成 
物の濃度に比例する。これらの結果に基づき，蒸解鉒 内での木材溶解固形分の濃度を減らすことで, 蒸解プ ロセス及びパルプ品質の雨力の改善を達成することが 可能となる。これが Lo-Solids (R) 蒸解法の基礎とな つている。

\subsection{Lo-Solids (R) 蒸解法の目的}

Lo-Solids (R) 蒸解法は, 改良蒸解法の 1 つである。 改良烝解法とは, 白液の多段添加, 可能な向流蒸解を 行なうことによって，以下の目的を達成するものであ る。

(1) 温度及び蒸解薬品の均一な分布

（2）均一なアルカリ濃度分布

(3) 蒸解温度ピークを最小とする

(4) 蒸解終了時での溶解リグニン濃度を最少とする この新しいLo-Solids（R）蒸解法ではこれらに加 えて多段抽出及び多段洗浄ろ液添加を行なうことで, 蒸解初期と蒸解後期の両方において, “全体の”木材 溶解固形分濃度を最少とするものである。

\subsection{Lo-Solids（R）蒸解法の基本原理}

これらのU的を達成するために，蒸解鉒（浸透べッ セルを含む）の数点から蒸解廃液を抽出することで, 木材溶解固形分が除去される。蒸解廃液中には, 高濃 度の溶解固形分と低濃度の残留蒸解薬品が存在する。 これらの蒸解廃液の抽出によって系内から溶解固形分 を排出し, 続く䅉解ゾーンへの侵入を防ぐ。その結果, 蒸解初期と蒸解最終段での副生:成物の “量” が減少す る。

木材溶解阁形分に加之, 各抽出点から水及び有効ア ルカリも系内から取り除かれることになる。系内での 水バランスを満足させるために, 補給水の添加が必要 となる。続く蒸解ゾーンでの必要な薬品を維持するた め, 補給蒸解楽品の添加も必要である。そのため, 予 熱された洗浄ろ液及び!液が抽出点の下流側で添加さ れる。これらの添加液中の溶解固形分濃度は非常に低 いので, 蒸解廃液抽出後に鉒内に残留している有機固 形分を希勫することになる。同時に，抽出により低下 した液比を高如, 繶く蒸解ゾーンで発生する副生成物 を希釈することになる。この補給液による希釈によっ て, 蒸解初期及び最終段での木材溶解固形分濃度が減 少する。

Lo-Solids (R) 蒸解法の基本原理は, 蒸解廃液の多 段抽出及びそれに続く予熱された洗浄ろ液と白液の添 加による液補給と希勫ということになる。抽出量と希 釈量の相対比を塥節することで, 反応時間の関数であ る副生成物の濃度, 有効アルカリ量そして硫化度の全 てが適切な範井に調節される。連続蒸解鉒のコンピュ
ーターシュミレーションによるモデルでは，この新技 術を用いることで蒸解初期及びその他のゾーンでの副 生成物濃度を従来の連鉒（単一の抽出と鉒ボトムから の単一の希釈）というプロセスに比較し，30\%程度低 減できると予想されている。

\section{4 プロセス機器の構成}

蒸解廃液は蒸解釜のスクリーンからフラッシュタン クへ抽出され，予熱された洗浄ろ液と白液は循環ライ ンから系内に供給される。そのため, Lo-Solids (R) 蒸解法の原理は, 液偱環システムを備えているどのよ うな連続蒸解鉒にも適用することが可能である。抽出, 補給そして希釈というシーケンスは，1回あるいは 2 回繰り返されるが，これは各システムの構成によって 異なる。既設鉒への適用における最終的なプロセス構 成は，その既設機器がどのように設計されているか (各スクリーン及びセントラルパイプの数と位置) で 異なる。例として，図6に示されるような 1 ベッセル 液相鉒の場合を示す。

既設鉒への適用に伴う必要な改造は，主として外部 配管及びバルブである。

\section{5 木材溶解固形分の減少}

図 7 では, EMCC 法と Lo-Solids (R) 蒸解法にお ける, 反応時間に対する副生成物（木材溶解固形分） のプロファイルを比較している。これらの結果は種々 の北方針葉樹によって ECF 漂白マーケットパルプを

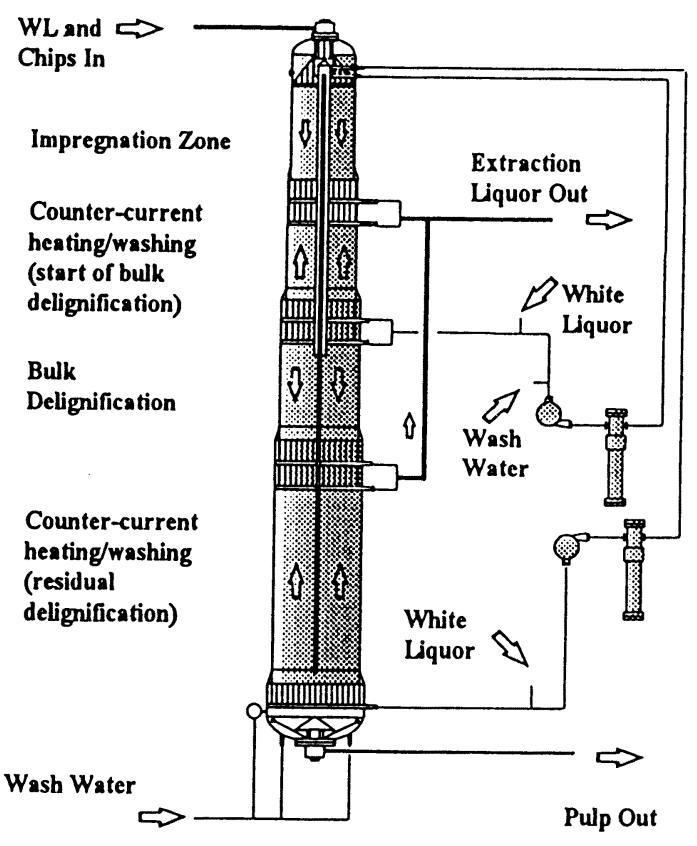

Fig. 6 プロセス機器の構成 


川上千明

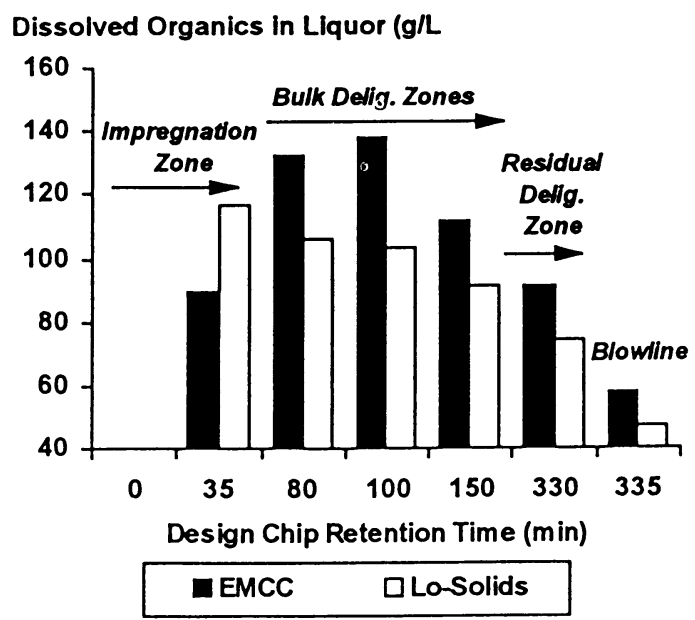

Fig. 7 副生成物比較

生産している工場から得られたものである3)。LoSolids (R) 蒸解法へ変わったことで, 蒸解初期及び 残りの脱リグニン反応において有機分濃度が10 $30 \%$ 減少したことが分かる。同梯の結果は既に報告さ れて抢り4) 9)，報告を行なっていない工場でも同様の 結果が観察されている。プロファイルの形状とその変 動については, 蒸解条件や蒸解プロセスの構成によっ て, 各工場間で異なる。どの測定結果からも, 蒸解鉒 のコンピューターシミュレーションに基づくモデルで 予想されたものと一致した。

4.6 パルプ強度, 有効アルカリ消費及び漂白性の 改善

以前に示されたラボでの結果 ${ }^{20), 21)}$ から, 他の条件 を一定として副生成物濃度（木材溶解固形分濃度）を 10３0\%減らすことで， 5 〜 10\%のパルプ強度の上昇， 2〜5\%のアルカリ消費量の減少及び 1 3\%の漂白性 の向上が予想された。蒸解の選択性の向上も予想され た。Lo-Solids (R) 蒸解法によって運転されているい くつかの実機において，これらの結果と比較を行なっ た。ラボで得られた結果から予想された効果が実機で もほとんど同様のものであり，その効果は副生成物濃 度プロファイルの減少に比例した。

ある工場において作成されたデー夕を図８に示す。 ここで強調しておきたいのは，パルプ強度に対する効 果の度合は, Lo-Solids (R) 蒸解法に変換することに よって得られた低い副生成物濃度に関連していること である。広葉樹蒸解では, 漂白後のパルプ粘度の 2 $10 \mathrm{cp}$ (Tappi 標準法)の上昇が報告されている）。

木材溶解固形分は, 生産に寄与しない 2 次反応でア ルカリを消費し，蒸解の選択性を低下させる。すなわ

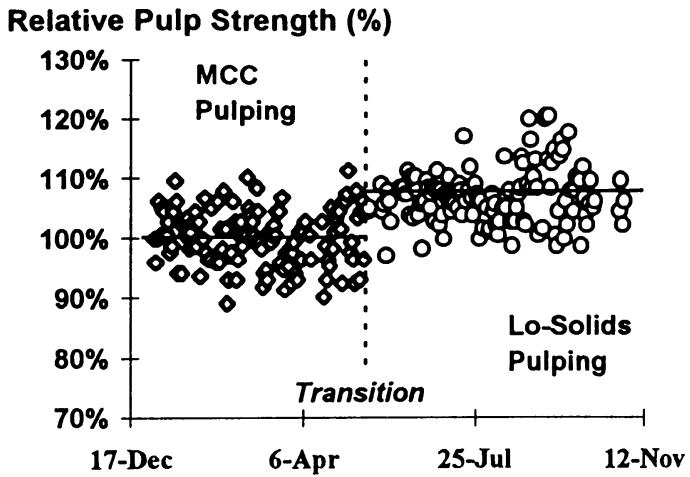

Fig. 8 Lo-Solids パルピングによるパルプ強度改善

ち，木材溶解固形分を減らすことは有効アルカリ消費 量を減らすことになり，白液添加最の減少につながる。 または, 白液添加量を一定としたまま, 蒸解温度を下 げることが可能である。Lo-Solids (R) 蒸解法に変換 することで得られる副生成物濃度の 10 ～30\%の減少 は，5１0\%の白液添加量の減少，または $2 \sim 5{ }^{\circ} \mathrm{C} の$ 蒸 解温度の低下，または 5 10\%のブローラインでの Kappa 価の減少をもたらす ${ }^{3 / 29) 。 し か し な か ゙ ら ， こ の ~}$ 副生成物濃度低下による効果は, これらの効果の全て を同時に実現できるほど大きいものではない。蒸解温 度を下げることを選んだ場では，最も大きなパルプ 粘度の改善が見られた。

従来法による蒸解から Lo-Solids（R）蒸解法に変 換した場合には，漂白性の大幅な向上が報告されてい る。あるケースでは，洗浄ゾーンでの向流洗浄を持た ない蒸解釜で, トータルでの Kappa ファクターの $20 \%$ 向上が報告されている ${ }^{6)}$ 。Lo-Solids (R) 蒸解 法の原理を適用することで, 洗浄ゾーンで少量もしく は全く向流を持たない蒸解釜に, 蒸解の選択性や漂白 性の向上などの利点を, パルプ強度の改善と共に得る ことができた。

4.7 蒸解釜からの抽出量の増加と末唒洗浄の向上

今日までの全ての Lo-Solids（R）蒸解法の適用に おいて，蒸解釜の抽出能力の大きな向上が見られた。 多段抽出と共に適正な補充液添加を行なうことで，千 ップコラムの動きを妨げることなく，木釜からの全抽 出量を増加することになる。全抽计量が増加するのと 同時に, 従来の主抽出スクリーンからの抽出液量もま た減少する。その結果, 蒸解釜の主抽出スクリーンで の負荷が減少し，ハンギング問題は解消した ${ }^{3) ~ 7) 。 ~}$

抽出量の増加は, 蒸解釜への洗浄万液添加量, つま り希釈係数の増加ということでもある。それはすなわ ち，釜内洗浄の改善を意味する。釜内での洗浄の状態 
は，ブローラインでのパルプ中に含まれる木材溶解固 形分濃度の测定によってわかる。図 8 の場合では, Lo-Solids (R) 蒸解法に変換したことによって，ブロ ーラインでの溶解有機固形分濃度が $30 \%$ 以上減少し た。同様の結果は，この測定を行なっているどの工場 でも見られた。Volkと Y oung ${ }^{7)}$ はブローラインのパ ルプサンプルでの COD 量の 15〜25\%の減少, 未醞洗 浄における消泡剂使用量の $18 \%$ の減少を報告してい る。ブローラインで見られた COD 量の減少は, 未晒 洗浄全体での COD 储が低くなったことにも関連する。 その後の Young, Volk 等 ${ }^{22)}$ は, a) ブローラインでの $\mathrm{COD}$ 值とパルプ強度, 酸素脱リグニン装置での滞留 時間の関係及び，b）ブローラインでの COD 值と漂 白第 1 段での薬品使用量の関係について報告している。 同様に, Martin 等 ${ }^{8)}$ は, Lo-Solids (TM) 蒸解法を 採用したことで末晒洗浄でのパルプ及び液中の金属が 11〜23\%減少したと報告した。この工場での未晒洗浄 後でのパルプけのマンガン量の減少は $20 \%$ 以上にも 及んだ。この事は TCF 漂古を行なう工場においては 非常に重装である。

\section{8 スケールの減少}

Lo-Solids (R) 蒸解法では, 浸透ゾーン後の液を蒸 解温度まで加熱する以前に系外へ抽出する。抽出液は 最高でも $145^{\circ} \mathrm{C}$ 以下，存機的に結合したカルシウムが 分離・析计し, スケールを生成する温度である $150^{\circ} \mathrm{C}$ よりも低い温度である ${ }^{23)}$ 。従って，木材と共に木釜内 に入って来なカルシウムの大部分は, プロセス機器上 にスケールを形成する湔に系外へ取出されることにな る。現尖に，ヒ一タ一及びスクリーンでの大幅なスケ 一ル減少となっている。スケール成長の速い工場で Lo-Solids (R) 蒸解法を導入したところでは，蒸解七 一ターのスケール除去作業の頻度は $1 / 10$ またはそれ 以下になった。

\section{9 温度プロファイルの改善}

Lo-Solids (R) 蒸解法におけるその他の大きな利点 は，蒸解釜の断面における温度分布の改善である。均 一な蒸解を得るためには, 断面方向での良好な温度と 蒸解薬品の分猔が必荘である。四 6 に示されるような 蒸解釜の場合, 従来法, MCC 及び EMCCでは初め の 2 つ蒸解循環で蒸解温度まで加温する。蒸解循環 では，スクリーンからチップコラム中の蒸解液を取出 し，この液を外部のヒーターで加温し，セントラルパ イプを介してチップコラム快蚛に戻す。断面方向に おける炵一な温度の分布を得るため, この抽出・循環 流量を十分高くとらなければならない。しかしながら このようなシステムでは，常に中心部の温度が高く，
外周部が低いという温度勾配が生じるのは明古である。 この温度勾配が大きくなると, 均一蒸解が得られず, ブローカッパ価が安定せずリジェクト量も大幅に増え てしまう。

Lo-Solids (R) 蒸解法では，これらの断面方向の温 度勾配を極少できる。これはまず第 1 に，蒸解温度へ のチップの加温が昇温された液に「向流」で行われる ことによる。一般に，チップコラムでの问流による夜 分散は, 単なる分散に比べてより均一である。したが って，上部及び下部蒸解スクリーン間の向流ゾーンで の温度分布は大きく改善される。第 2 に, 浸透ゾーン からの浸透に使われた多量の蒸解廃液は，加温される ことなく系外に抽出される。この抽出廃液は, その一 部を白液及び洗浄乃液と置換された上でヒ一ターによ り設定温度まで予熱され，セントラルパイプを通じて 木釜へ戻される。したがって，Lo-Solids (R) 蒸解法 では，抽出外部での予熱を行なわなければならない千 ップコラム中の液量が非常に少ないのである。言い換 えれば，循環単位流量当りでのチップコラム液の循環 回数が非常に大きくなる。第 3 に, 向流蒸解ゾーンで の液比を, 従来法及び改良蒸解法に比べて低く調節す ることができる。その結果, 反応熱によるチップコラ 厶温度上昇がより顕著となる。蒸解薬品が良好に分布 されている場合，反応熱は非常に均一である。

実際には, 蒸解循環での断面力向の温度勾配は, 蒸 解ヒーター出口温度とスクリーン抽出温度の比較で行 われる。全ての場合で, Lo-Solids (R) 蒸解法の適用 によって，この温度勾配の減少が見られた。具体例と しては，7〜 $10^{\circ} \mathrm{C}$ あた勾配が 2 $3^{\circ} \mathrm{Cに下がっている。}$ 更に, 全ての 1 ベッセル蒸解釜で上部蒸解循環を完全 に止めることが可能であることがわかった（従来法及 び改良蒸解法ではこの循環でヒータ一を用いて昇温を おこなっている)。このようにして，少ないプロセス 機器で温度分布の改善を図ることができる。

\subsection{Lo-Solids（R）蒸解法の気相釜への応用}

最近，気相シングルベッセル連続蒸解釜に $\mathrm{LO}^{-}$ Solids (R) 蒸解法が応用された。その結果, 注目す べき効果が得られた。

気相釜は木釜内に入って来た木材チッブを直接蒸気 で加温する。換言すれば十分な薬液浸透を行わずに蒸 解反応が開始される。薬液がチップ内部まで完全に浸 透していないため, 均一な蒸解度が得られずブローラ インの Kappa 価の変動, 多量のリジェクトが発生し ていた。Lo-Solids (R) 蒸解法の導入により, 木釜上 部スクリーンからの抽出後補充薬液, 洗浄ろ夜を加之 ヒーターを経由して向流加熱を行った結果, 効果的で 
均一な蒸解温度プロファイルが得られた。このため釜 頂部への直接蒸気を全く必要としなくなり, 釜頂部温 度は約 $30^{\circ} \mathrm{C}$ 低下し，木釜上部は効果的な浸透ゾ一 ンとして機能し，ブローラインKappa の安定化，リ ジェクトの減少というパルプ品質の向上をもたらした。 この他, 操業性の向上, 蒸解薬品の節減, 蒸解温度の 低減，パルプ強度及び漂白性の向上などの効果が得ら れているが,この気相釜に於けるLo-Solids (R) 蒸 解法の応用については別途報告される予定である。

\section{5. ま と め}

新しい大気圧式プレスチーミングシステムが開発さ れた。Diamondback (TM) プレスチーミングシステ ムは現時点で 11 工場で良好に運転中である。この新 システムによって，より均一かつ十分なチップのプレ スチーミングと信頼性の高い, メンテナンスフリーの 操業が可能となった。

米国 Gulf Stateの Demopolis 工場での Lo-Level (TM) 供給システムは良好に運転されている。この システムは 1996 年 2 月以降連続的に使用されている。 期待通りのより良いスチーミングが得られた。低温で の浸透による操業は安定している。高圧フィーダーの 能力増も確認された。その他のテストが計画されてい るが, この新システムは旧式のチップ供給システムに 取って代わるものと思われる。

従来法又は改良蒸解法によるプロセスと比べて, Lo-Solids (R) 蒸解法でのいくつもの蒸解釜全体の改 善が可能である。パルプ強度の向上, 蒸解薬品と漂白 薬品の低減, 蒸解釜からの抽出量の増加, 未晒洗浄の 改善, 蒸解釜でのスケール形成の減少及びより均一な 蒸解温度分布がこれにあたる。改造の場合, 向流が小 さい又は全くない蒸解釜に対して, Lo-Solids (R) 蒸 解法は改良蒸解法で得られる利点を提供する。その多 くの利点のため, 既設釜のアップグレード及び新しい 蒸解釜への標準法としてLo-Solids (R) 蒸解法は世 界中に急速に採用されて来ている。

Ahlstrom Machinery Inc. 社で開発されたこれら 3 つの新技術を併せたものは，連続蒸解釜技術におけ る大きな進歩をもたらした。

最後に, 多くの方がこれら新技術開発の成功に貢献 した事を述べておきたい。特に, Richard Laakso, Wayne Chamblee, Jerry Johanson, Geoffrey McClain, Jimmy Edmonds, Joeanne Volke, John Allen 及びGerry Williamsの各氏, 及びこれ ら全ての考案・開発の中心的役割を果たした James Robert Prough 氏に厚く感謝したい。

\section{参考文献}

1) B. Marcoccia, J. R. Johanson, G. Williams, and P. Bruce: Proc. Pacific Paper '95, pp 8-14, Vancouver B. C. (Oct 1995).

2) W. Chamblee, E. Funk, B. Marcoccia, J. R. Prough, and G. McClain: Proc. 1996 Tappi Pulping Conf., Nashville TN (Oct 1996).

3) B. Marcoccia : Proc. Ahlstrom Japan Technology Seminar, pp 1-18, Tokyo (March 1994).

4) K. Gosh : Proc. 1995 TAPPI Emerging Pulp. and Bleach. Tech. Workshop, No. 3, Durham NC, (May 1995).

5) L. Sammartino-Pulp Paper Canda 97(3):61 (March 1996)

6) B. Marcoccia, R. Laakso, G. McClain, : Tappi J. 79(6) : 179 (June 1996)

7) J. Volk and J. Young: Proc. 82 nd Annual Mtg. Tech. Sect. CPPA, pp B 37-B 42, Montreal PQ, (Jan 1996).

8) F. Martin, J. Nepote, K. Girard, A. Jaegel, Y. Gu and L. Edwards-Proc. Tappi Min. Effluent Mill Symp., Atlanta GA, (Jan 1996).

9) Edwards et al. : "Toward Mill Closure: Lessons Learned", presented at 1996 Tappi Con, Atlanta, GA

10) J. R. Phillips: Kamyr, Inc. Tech. Bulletin No. KGD 1790-W 85, (1985).

11) J. R. Johanson: Trans. SEM, $232: 69$, (March 1965).

12) A. W. Jenike, and J. R. Johanson : CIM Trans. $73: 141,(1970)$.

13) J. R. Johanson: Proc. Powder and Bulk Solids Conf., Chicago Ill, (1988).

14) J. R. Johanson : Chem. Eng., pp 77-86, (Jan 1979).

15) J. R. Johanson, : Binside Scoop 7(1), (1994).

16) J. R. Johanson, : Binside Scoop 6(1), (1993).

17) D. R. Elliot: Pulp and Paper 38(26):27 (1964).

18) W. A. Hunt: Forest Products Journal 13 (19) : 365 (1963).

19) J. Gullichsen, J. and H. Sundvist, H. : Proc. 1995 Tappi Pulping Conf., pp 227-234, Chicago Ill., (Oct 1995). 
20) B. Marcoccia: Proc. 82 nd Annual Mtg. Tech. Sect. CPPA, pp B 265-B 274, Montreal $\mathrm{PQ}$, (Jan 1996).

21) B. Marcoccia, Proc. 50 th Annual APPITA Conf., Auckland NZ, (March 1996).

22) J. Young, J. Volk, G. Start, H. Klaver, J. Cushner, R. Baczynski, T. Calaiezzi, K.
Brown, R. Ellis, "Physical : Chemical Interactions Affecting Control in the Modern Fibreline", preprint from the 82 nd Annual Meeting Technical Section CPPA, Montreal, January 1996.

23) N. Hartler and J. Libert: Svensk Papperstidning, nr 12, 454 (1973). 